\title{
Cardiac regenerative capacity: an evolutionary afterthought?
}

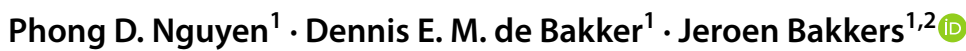

Received: 11 January 2021 / Revised: 23 March 2021 / Accepted: 29 March 2021 / Published online: 5 May 2021

(c) The Author(s) 2021

\begin{abstract}
Cardiac regeneration is the outcome of the highly regulated interplay of multiple processes, including the inflammatory response, cardiomyocyte dedifferentiation and proliferation, neovascularization and extracellular matrix turnover. Speciesspecific traits affect these injury-induced processes, resulting in a wide variety of cardiac regenerative potential between species. Indeed, while mammals are generally considered poor regenerators, certain amphibian and fish species like the zebrafish display robust regenerative capacity post heart injury. The species-specific traits underlying these differential injury responses are poorly understood. In this review, we will compare the injury induced processes of the mammalian and zebrafish heart, describing where these processes overlap and diverge. Additionally, by examining multiple species across the animal kingdom, we will highlight particular traits that either positively or negatively affect heart regeneration. Last, we will discuss the possibility of overcoming regeneration-limiting traits to induce heart regeneration in mammals.
\end{abstract}

Keywords Regeneration - Repair $\cdot$ Evolution $\cdot$ Scar $\cdot$ Extracellular matrix $\cdot$ Inflammatory response $\cdot$ Cardiomyocyte $\cdot$ Proliferation

\section{Introduction}

Regeneration is an injury induced process that can be considered as a combination of multiple synergistic processes that act not only to limit the injury, but also generate new cells to replace the loss of tissue. This regenerative response varies widely within the animal kingdom and can be viewed at multiple biological levels ranging from regeneration of a whole body part, a specific structure or organ, a tissue and to an individual cell [1]. When viewing organ regeneration, in particular the heart, there is considerable variation [2]. Mammalian hearts for example typically lack a regenerative response upon injury, and instead form a permanent scar. Other species, including the fish species Medaka (Oryzias latipes) $[3,4]$ and cave-dwelling Astyanax mexicanus [5], show a similar limitation when it comes to cardiac

Phong D. Nguyen and Dennis E.M. de Bakker contributed equally.

Jeroen Bakkers

j.bakkers@hubrecht.eu

1 Hubrecht Institute-KNAW and University Medical Center Utrecht, Utrecht, Netherlands

2 Department of Pediatric Cardiology, Division of Pediatrics, University Medical Center Utrecht, Utrecht, Netherlands regenerative capacity. In contrast, a wide range of species have been shown to contain robust cardiac regenerative capacity, including the giant danio (Devario aequipinnatus) [6], goldfish (Carassius auratus) [7], newts (Notophthalmus viridescens) $[8,9]$, Mexican Axolotl (Ambystoma mexicanum) [10-12] and surface-dwelling Astyanax mexicanus [5]. However, the most commonly used animal to study cardiac regeneration is the zebrafish (Danio rerio), which was first reported in 2002 to contain a robust regenerative capacity from amputation of ventricular tissue [13]. Following this seminal study, there have been a plethora of studies examining the cellular and molecular mechanisms contributing to the regenerative response.

Interestingly, cardiac regenerative capacity does not only differ among species, or even sub-populations as is the case with Astyanax mexicanus, but also between genetically identical organisms at different life stages. Indeed, several mammalian species have been reported to have a short timewindow after birth where they retain regenerative capacity of the heart. For example, neonatal mice can regenerate their heart from injury either via amputation [14] or myocardial infarction (MI) [15] during the first 7 days post birth, with some indication that the regenerative window is restricted to the first 2 days post birth [16]. The neonatal pig also displays this phenomenon whereby its regenerative window lies 
within their first 2 days post birth [17, 18]. Additionally, there have been clinical reports of human newborns recovering from a MI to various degrees $[19,20]$.

In this review, we will describe the heterogenous distribution of cardiac regenerative capacity between species. In doing so, we hope to shed light on the processes and traits which cumulatively allow for successful heart regeneration. To achieve this goal, we will first describe processes occurring in mammalian heart repair and zebrafish heart regeneration, indicating where the two process overlap or diverge. Next, we will broaden our scope to include additional species, identifying traits that either positively or negatively affect heart regeneration. Lastly, we will discuss whether these differential processes and traits can be overcome to allow for heart regeneration in mammals.

\section{Repair vs regeneration: differences between poor and robust regenerators}

The repair response following heart injury is shared between zebrafish and mammals. This includes processes involving regulation of cellular stress, the immune system and extracellular matrix deposition that limit the deleterious nature of the injury and secures immediate survival. There are some differences in this repair response when comparing between zebrafish and mammals. Meanwhile these differences become more apparent as time progresses, whereby non-regenerating hearts continue to form a mature and permanent scar while regenerating hearts enter a new phase to replace the lost tissue. Here, we will highlight the shared and differential processes between heart repair and regeneration.

\section{Extracellular matrix (ECM) deposition}

While the adult mammalian heart does not regenerate, it is quite efficient at repair. Indeed, patient fatality from the direct effects of a MI (e.g., heart rupture) is rare. Instead, patients often succumb to mortality from the long-term effects such as cardiomyocyte (CM) hypertrophy, chamber dilation and ultimately heart failure. One factor that contributes to the prevention of heart rupture and direct lethality post $\mathrm{MI}$ is the highly coordinated deposition of a dynamic extracellular matrix (ECM) network [21]. This reparative process can be divided into three distinct phases: The Inflammation, Proliferative and Maturation phase [21]. During the inflammation phase, necrotic tissue as well as the native ECM is broken down through the activity of matrix metalloproteases (MMPs) [22, 23]. Simultaneously, increased permeability of vessels bordering the injured area allows for the influx of fibrinogen, forming a provisional fibrin-based matrix network [24, 25]. Through the proliferation phase, which is marked by the proliferation of (myo) fibroblasts, the fibrin-based network is gradually replaced with fibronectin and collagenous type-III filaments secreted by myofibroblasts and macrophages [26-28]. Finally, in the maturation phase, the fibrinous collagen type-III network will be replaced by collagen type-I filaments, which are highly cross-linked and provide robust structural integrity and therefore increasing scar stiffness [29, 30]. Although these ECM dynamics ensure the immediate survival and short-term integrity of heart morphology, the formation of a fully matured, permanent scar leads to adverse effects later in life [31, 32].

ECM deposition during zebrafish heart regeneration also involves the formation of a provisional fibrinous network and consequent replacement by collagenous filaments similar to that seen during mammalian heart repair $[33,34]$. However, differences arise when addressing the origin of ECM in the regenerative heart. Besides activated fibroblasts, endocardial cells contribute to ECM production during zebrafish heart regeneration [35]. In addition, the source of pro-fibrotic fibroblasts differs between zebrafish and mammalian hearts. Upon injury, resident fibroblasts of the mammalian heart migrate to the injury site, proliferate and differentiate into pro-fibrotic myofibroblasts under the regulation of TGF- $\beta$ [28]. In contrast, the pro-fibrotic fibroblasts of the regenerating zebrafish heart not only arise from resident fibroblasts but are also formed by trans-differentiation of epicardial cells [36-38]. Like mammalian fibroblasts, zebrafish fibroblasts are activated through TGF- $\beta$ signalling to acquire a pro-fibrotic signature, referred to as activated fibroblasts [36]. However, as regeneration progresses these fibroblasts are gradually de-activated to prevent excessive fibrosis [38] and the produced ECM is ultimately replaced by new functional myocardium. The regression of the ECM is dependent on MMPs (such as mmp2 and mmp14a/b) [39] cleaving the collagenous network. However, MMPs might have additional functions during the inflammation phase. Indeed at 4 days post cryoinjury, MMPs are highly expressed by vimentin + fibroblasts (including $\mathrm{mmp} 9$ and $\mathrm{mmpl3}$ ) [40]. In addition, $m m p 2$ and $m m p 14 a / b$ have been shown to be expressed during the inflammation phase 3 days post cryoinjury. In contrast, the upregulation of $\mathrm{mmp} 2$ and $\mathrm{mmp} 14 \mathrm{a} / \mathrm{b}$ only occurs at $7 \mathrm{dpi}$ in the apical resection model, which lacks necrotic tissue. This suggests that post cryo-injury, MMPs could play a role in clearance of the necrotic tissue during the inflammation phase. Whether differences in MMP expression could underly differential scar regression between the injured zebrafish and mouse hearts, or whether the difference is due to a change in deposition rate, remains to be elucidated. Besides differences in the origin and temporal dynamics of cardiac fibroblasts and fibrosis, differences in ECM composition are also observed between regenerating and non-regenerating hearts. Interestingly in neonatal mice, the ECM 
component Agrin is highly expressed during the regenerative window and is downregulated thereafter [41]. This enrichment of Agrin expression is important for promoting $\mathrm{CM}$ proliferation and injection of this proteoglycan following adult heart injury improves cardiac function [41, 42]. Whether Agrin is expressed during zebrafish heart regeneration has not been reported, however administration of zebrafish ECM into the MI-induced adult mouse hearts facilitated cardiac functional recovery [43]. This was similarly observed with injection of neonatal cardiac ECM [44]. Thus, showing that ECM components can possess a pro-regenerative role.

Taken together, ECM depositions like fibrin and collagen are shared between the repair and regeneration processes, albeit with differences in their establishment and clearance. Like in the injured mammalian heart, collagen I is expressed in the injured zebrafish heart at 14 days post cryo-injury [45]. Differences between zebrafish and mammalian ECM maturation arise after the initial deposition of collagen I. Mammalian hearts maintain the production of collagen I fibres resulting in a stiff permanent scar. In contrast, the zebrafish heart shows a transient de-activation of pro-fibrotic fibroblasts, thereby limiting the amount of deposited fibrosis [38]. In addition, the zebrafish heart dissolves the initially deposited ECM (including the collagen I network) through the expression of MMPs. To which extend the reduced deposition and/or clearance of the deposited collagenous network determines the transient nature of the zebrafish fibrotic response remains unclear. In addition, it remains to be elucidated which specific differences arise between initial scar deposition between the zebrafish and mammalian heart. The differences in ECM scar composition between regenerating and non-regenerating hearts draw parallels to other forms of regeneration. Spinal cord regeneration in zebrafish for example display a transient stiff ECM that is proposed to stabilize the injury and change to a less stiff ECM to facilitate neuron migration into the injury area ([46], and reviewed in [47]). A similar mechanism may happen in cardiac regeneration to allow for $\mathrm{CM}$ to enter and repopulate the scar. Indeed, it has been shown that ECM stiffness correlates to the regenerative window in neonatal mice hearts. Whereby an increase in stiffness correlated with the lost regenerative capacity, while reducing stiffness by addition of an inhibitor at a stage when the regenerative window was closed resulted in the maintenance of regenerative competence [16]. Moreover, ECM production is important for regeneration and repair as ablating collagen producing cells from the injured zebrafish heart leads to impaired heart regeneration [38] and ablating myo-fibroblasts from the post-MI murine heart leads to decreased survival [48]. Furthermore, the composition of the ECM strongly influences the outcome of the heart regeneration and repair processes $[49,50]$.

\section{Innate immune system}

The inflammatory response is a well-orchestrated, complex process that plays an indispensable role during cardiac repair in mammals. The start of the inflammation phase is marked by the recruitment of neutrophils to the infarct area, which secrete pro-inflammatory signals and attract monocytes to infiltrate the infarction. Resident cardiac macrophages have been shown to recruit monocytes originally derived from the spleen. These monocytes will differentiate into macrophages and play multiple roles while occupying the injury site [51, 52]. This review will conveniently define these roles into two phases (M1 and M2), the separation of these states is much more complex and still not well understood. Nevertheless, these macrophages acquire pro-inflammatory properties (M1) [53] and together with neutrophils will secrete various MMPs that allow for the remodelling of the native ECM [54]. At the same time, damaged and dying cells in the infarct site will activate the complement system, marking necrotic cells for degradation and phagocytosis thereby clearing the infarcted area of dead and necrotic cells [53, $55,56]$. Next, during the proliferative phase, apoptotic neutrophils are cleared from the tissue through phagocytosis by the M1 macrophages, which now progress into a new state (also known as M2) that is marked by the secretion of antiinflammatory signals [57]. During this phase, a collagenous ECM is produced that is rich in fibronectin. Although myofibroblasts are the main contributors to ECM deposition, it is thought that the $\mathrm{M} 2$ macrophages play a regulatory role in ECM turnover through the secretion of MMPs and their inhibitors, TIMPs (reviewed in [58]). In addition, M2 macrophages secrete TGF- $\beta$ ligands, thereby activating the collagen production in myofibroblasts $[28,59]$. During the final maturation phase, collagen deposition is halted and the more loosely organized collagen III is replaced with a tightly cross-linked type I collagen. The role of the innate immune system in this part remains largely unexplored. The role of resident cardiac macrophages has also been shown to play an important role in activating angiogenesis and $\mathrm{CM}$ proliferation in neonatal cardiac injury $[52,60]$. As well as modulating proinflammatory monocyte macrophages following adult cardiac injury [52].

During regeneration in zebrafish, a similar influx of neutrophils and a presence of various sub-populations of macrophages is observed $[3,61,62]$. A distinct $\mathrm{Wt} 1+$ macrophage sub-population, which at least partially arise from the hematopoietic niche was identified that displays a pro-regenerative transcriptomic signature [63]. It remains uncertain how the macrophage populations in the zebrafish compare with the mammalian macrophages. Besides the 
innate immune system, a recent study indicates that the acquired immune system plays an indispensable role during zebrafish heart regeneration and suggests that differences in the adaptive immune system might underlie differences in regenerative capacity [64]. It would be interesting to determine whether these unique macrophage cell states/subtypes found in zebrafish could be manipulated in mammalian macrophages to potentially improve regeneration.

\section{Revascularization}

During a myocardial infarction in patients, a blood clot restricts blood flow of a coronary artery. This limits the transport of nutrients and oxygen to the downstream region of the heart and cause massive ischemic tissue damage. There has been reports suggesting that injury-induced VEGF signalling leads to local neovascularization, which is a process detrimental to prolonged survival after MI [65-67]. Indeed, the initiation of angiogenesis starts as early as the inflammation phase and continues well into the proliferative phase $[66,68,69]$. First, newly formed vessels are hyperpermeable due to the lack pericytes and smooth muscle cells, allowing the infiltration of leukocytes into the ischemic area. Afterwards, under the influence of PDGF, these vessels obtain a mural coat existing of pericytes and smooth muscle cells reducing permeability [70, 71]. Interestingly, supplying murine ischemic hearts with human pericytes reduced vessel permeability and leukocyte infiltration, which led to beneficial effects on cardiac remodelling. This indicates that targeting neovascularization could have beneficial effects post MI $[72,73]$. However, as the infarcted area is remodelled into a mature scar largely devoid of living cells, the demand for nutrients and oxygen plummets. Therefore, as the scar matures the newly generated vasculature becomes obsolete and diminishes accordingly $[74,75]$.

During regeneration, like during repair, the revascularization is of vital importance. Indeed, revascularization as well as lymphangiogenesis of the injury area is important for efficient heart regeneration in zebrafish [76-78]. Both zebrafish and mammalian revascularization depends on VEGF-signalling, which is expressed in the injury area as early as $15 \mathrm{~h}$ (zebrafish) and $6 \mathrm{~h}$ (rats) post heart damage [65, 76]. Indeed, injury-induced VEGF has been shown detrimental to prolonged survival after MI in mammals [65-67] and blocking angiogenesis through expression of a dominant-negative Vegfaa blocks cardiomyocyte proliferation and heart regeneration in the zebrafish [76]. The biggest difference is therefore not in the initiation, but in the maintenance of the regenerated vessels. Whereas in the non-regenerative hearts the new blood vessels have no function as the scar matures, regenerated tissue retain their vasculature to support the newly formed high nutrient-/oxygen-dependent CMs. Taken together, revascularization plays a vital role during both repair and regeneration, but is only maintained following regeneration.

\section{Cardiomyocytes}

Cardiomyocyte proliferation in mammals is rare and occurs at a very low rate [79-81]. However, this does not increase nor significantly compensate for the millions of CMs that are permanently lost due to myocardial infarction. One strategy for the surviving CMs to counteract the reduced functionality of the heart is by growing in cell size. Although this hypertrophic response is rapid and quite efficient, it is often not sustainable in the long term. Indeed, many patients that suffered a myocardial infarction end up with pathogenic hypertrophy of the heart, ultimately resulting in heart failure $[31,32]$. CMs directly adjacent to the ischemic area, also called border zone CMs, respond in an even more dramatic manner. In order for them to survive the adjacent infarction, they partly dedifferentiate towards a more immature state $[82,83]$. This occurs through the replacement of a MEF2driven gene program, defining adult $\mathrm{CM}$ cell fate, with a stress-responsive AP-1-driven gene program allowing for survival under ischemic conditions [84]. Indeed, knock-out of one of these border zone stress responsive factors, $n p p b$, results in acute death following myocardial infarction in mice [84].

Instead of displaying a hypertrophic response due to cardiac insult in mammals, regenerative species respond with a hyperplastic response. In the zebrafish heart, the CMs that are lost by the injury are replaced by proliferation of existing CMs in the border zone $[85,86]$. In doing so, the heart will be restored to its original properties and deposited fibrosis will be replaced by new functional myocardium [13, 34]. Border zone CMs in the regenerating heart also dedifferentiate and activate a stress program indicated by the expression of stress induced genes such as members of the AP-1 complex (i.e., junba, junbb, fosab, foslla) as well as nppa and $n p p b$, much like mammalian border zone CMs during heart repair [84, 87]. However, this cellular reprogramming seems much more pronounced because it includes metabolic reprogramming from a fatty acid towards glycolysis dependent ATP production $[88,89]$, as well as the re-activation of an embryonic gene program [37, 85]. Indeed, a recent study has shown that the transcriptome of zebrafish border zone $\mathrm{CMs}$ is more similar to embryonic $\mathrm{CMs}$ then to remote myocardial CMs originating from the same hearts [88]. This reversion back to an embryonic state is likely key to unlock their proliferative potential as inhibiting their dedifferentiation, including the induction of glycolysis, prevents CMs from proliferating effectively [86-89].

Taken together, the reparative heart employs a hypertrophic response to deal with the loss of heart functionality, while the regenerative heart instead uses hyperplastic 
regrowth. Although the hypertrophic response forms an adequate short-term solution, it leads to severe problems in the long term, including complete heart failure. Border zone $\mathrm{CM}$ of both the reparative and regenerative heart dedifferentiate and activate a stress response program. However, this response seems to deviate in the regenerative heart, where the dedifferentiation results in the initiation of an embryonic-like gene program and the induction of glycolysis, while in the mammalian BZ many genes with high expression in neonatal CMs are not induced [84]. The induction of the embryonic-like gene program, including the induction of glycolysis, might help explain why zebrafish BZ CMs proliferate while mammalian BZ CMs do not re-enter the cell-cycle. Another explanation for the limited proliferative capacity of mammalian BZ CMs might be due to the intrinsic properties of cardiomyocyte nuclei. While mammalian
CMs are mainly polyploid (human) or multinuclear (mice), zebrafish CMs are mononuclear and diploid, which has been shown to be detrimental for efficient proliferation and zebrafish heart regeneration [90-92].

In summary, while the reparative and regenerative response show many similarities, distinct differences are observed as well (Fig. 1 and Table 1). Specifically targeting individual differences might help to stimulate the regenerative response in endogenously reparative species such as mammals.

\section{Regenerative traits: processes that facilitate a positive environment for regeneration}

As discussed above, for cardiac regeneration to occur, many independent processes have to be precisely regulated and

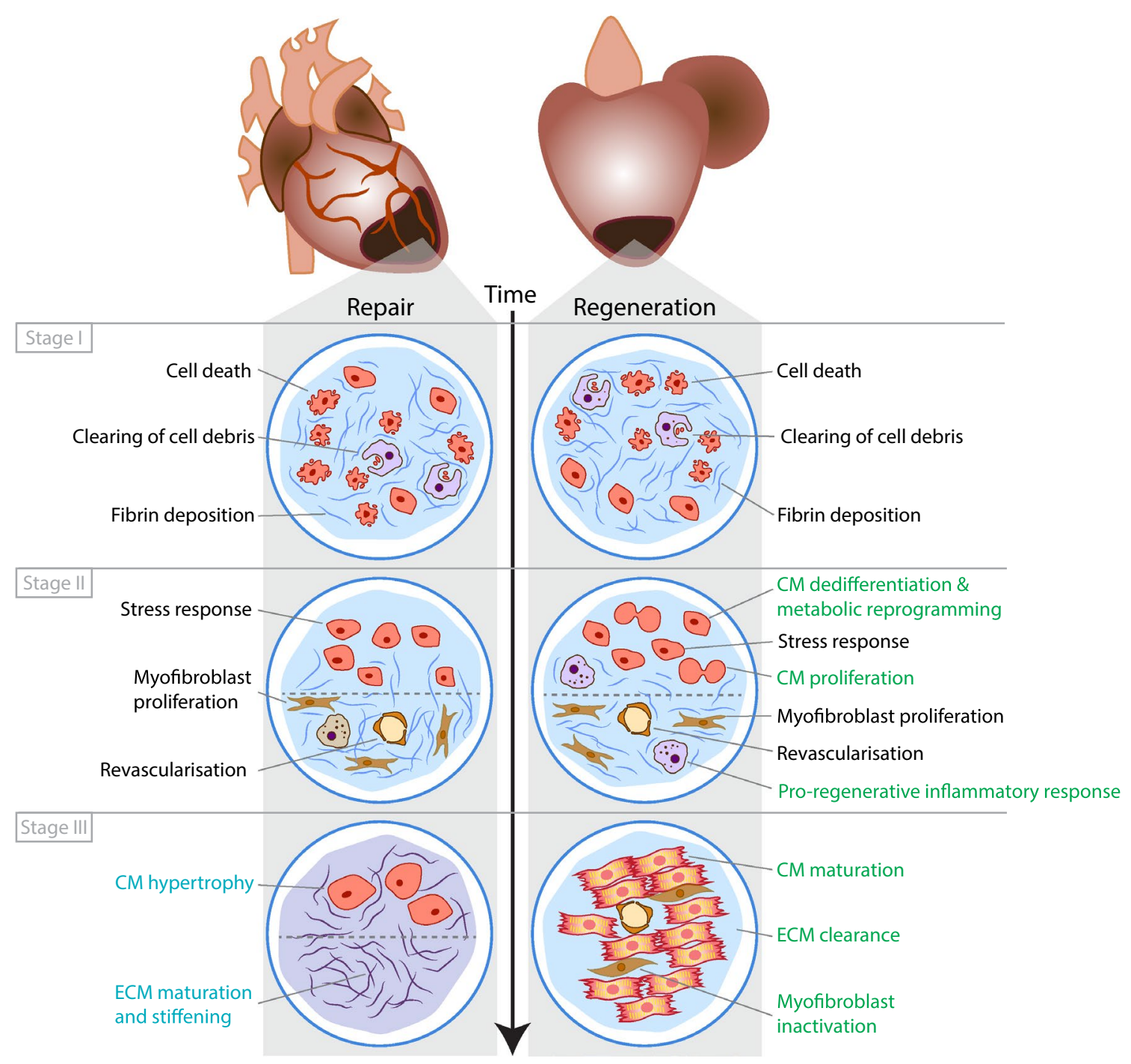

Fig. 1 Comparison of repair vs regenerative response following cardiac injury. Schematic summary of the main processes and their response in animals that can either repair or regenerate following cardiac injury. This is also summarized in Table 1 
Table 1 Comparing adult mammalian heart repair with zebrafish heart regeneration

\begin{tabular}{lll}
\hline Process & Repair & Regeneration \\
\hline ECM deposition: fibrin & Yes & Yes \\
ECM deposition: collagen & Yes & Yes \\
ECM maturation & Yes & No \\
ECM clearance & No & Yes \\
Innate immune system: neutrophils & Yes & Yes \\
Innate immune system: inflammatory macrophages (M1 phase) & Yes & No? \\
Innate immune system: anti-inflammatory macrophages (M2 phase) & Yes & Yes? \\
Neovascularization & Yes & Yes \\
Stress response border zone CMs & Yes & Yes \\
Reverting back to embryonic state/metabolic reprogramming & No & Yes \\
CM proliferation & No & Yes \\
CM hypertrophy & Yes & No
\end{tabular}

aligned. Recent studies have indicated the existence of regeneration-specific enhancers, which might have originated from repurposed injury responsive enhancers [93-95]. In fact, the loss of regeneration-specific enhancers might explain the lack of a regenerative response in some species [93]. While positive natural selection might occur on regeneration as a single unit, i.e., by maintaining regenerationspecific enhancer elements, competition for selection will likely also occur on the level of the individual processes constituting regeneration. In other words, environmental changes might force adaptations in a certain trait which is beneficial for the survival of the species, while being incompatible with cardiac regeneration. The second possibility is that a lack of evolutionary pressure (relaxed selection) would lead to the disappearance of cardiac regenerative capacity due to neutral evolution. The evolutionary mechanism leading to limited regenerative capacity is likely to differ between animal species and remains currently unresolved for mammals. In this section of the review, we will discuss the most prominent traits that impact cardiac regeneration. Furthermore, we will provide examples of species that have adapted these regeneration-compatible traits, likely losing the ability to regenerate their hearts in the process (Fig. 2 and Table 2).

\section{Regeneration trait: cellular roles of macrophages}

As mentioned above, the innate immune system, in particular the inflammatory response is one of the first responses to an injury. Aside from phagocytosing cellular debris at

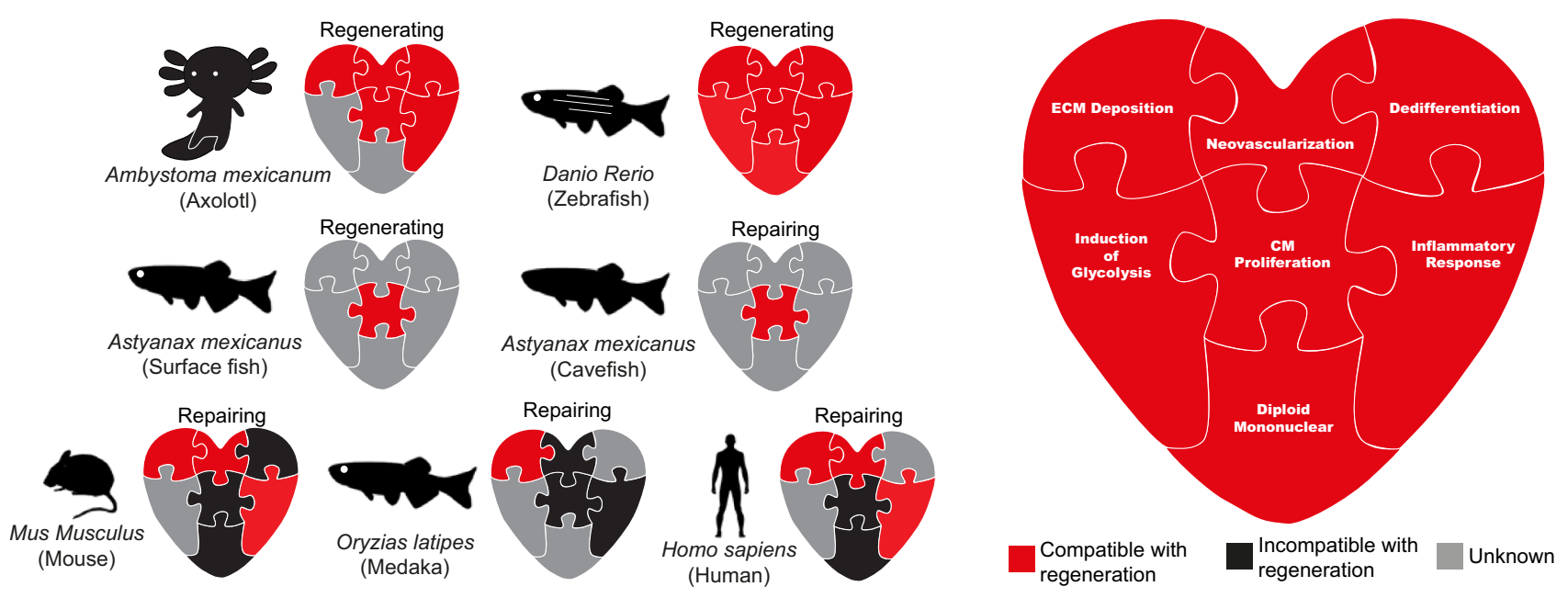

Fig. 2 Regenerative traits viewed as pieces of a jigsaw that facilitates cardiac regenerative capacity. Summary of the current literature in regards to a specific regenerative trait and whether it can facilitate normal adult cardiac regeneration in Axolotl, Zebrafish, Human, Medaka, Mouse and Cavefish. Red represents confirmed trait involved in facilitating regeneration. Black represents confirmed trait that is incompatible with regeneration. Grey represents traits in which have not been directly tested. References for these traits are summarized in Table 2 
Table 2 Summary of the known and unknown literature of cardiac regenerative capacity in various species

\begin{tabular}{|c|c|c|c|c|c|c|}
\hline & $\begin{array}{l}\text { Ambystoma mexi- } \\
\text { canum (Axolotl) }\end{array}$ & Danio rerio (Zebrafish) & $\begin{array}{l}\text { Homo sapiens } \\
\text { (Humans) }\end{array}$ & $\begin{array}{l}\text { Oryzias latipes } \\
\text { (Medaka) }\end{array}$ & $\begin{array}{l}\text { Mus musculus } \\
\text { (Mouse) }\end{array}$ & $\begin{array}{l}\text { Astyanax } \\
\text { mexicanus } \\
\text { (Cavefish) }\end{array}$ \\
\hline ECM deposition & {$[10,11]$} & {$[33,34]$} & [84] & {$[3,4]$} & {$[84]$} & [5] \\
\hline Neovascularization & {$[10,11]$} & {$[76]$} & {$[67]$} & {$[3,4]$} & [73] & Unknown \\
\hline Dedifferentiation & {$[10,11]$} & {$[37,85]$} & Unknown & Unknown & {$[84]$} & Unknown \\
\hline Metabolic reprogramming & Unknown & {$[88,89]$} & Unknown & Unknown & Unknown & Unknown \\
\hline $\mathrm{CM}$ proliferation & {$[10,11]$} & {$[13,96]$} & [79] & {$[3,4]$} & {$[14,15]$} & [5] \\
\hline Inflammatory response & {$[10,11]$} & {$[63,97,98]$} & [99] & [3] & {$[100]$} & [5] \\
\hline Diploid mononuclear & Unknown & {$[90]$} & [101] & Unknown & {$[81,102]$} & Unknown \\
\hline
\end{tabular}

the injury area, macrophages also play multiple roles in the subsequent cellular responses. For example, they can mediate the fibrotic response and directly contribute to collagen deposition [103], promote neoangiogenesis [3, 52, 100, 104] and initiate $\mathrm{CM}$ proliferation $[52,105]$. The importance of this cell population becomes apparent when overall depletion or ablation of specific macrophage subsets in zebrafish result in impaired regeneration with a decrease in CM proliferation and increase in scar formation [3, 63, 97, 98, 106].

The importance of macrophages during cardiac regeneration can also be observed in other species. In Medaka fish, heart regeneration does not occur and coincides with a delayed and reduced macrophage recruitment [3]. Meanwhile salamanders (axolotl), which are normally proregenerative display an inability to regenerate following macrophage depletion [10]. Likewise, macrophage depletion in neonatal mice following cardiac injury during the regenerative window resulted in an increase of fibrotic scar formation and decrease in cardiac output despite displaying a normal CM proliferation rate typically seen during regeneration [100]. All together these studies point to the positive role of macrophages in creating a permissive environment for regeneration.

The primary role of the innate immune system (and critically the M1 macrophages) is to defend from infection and repair damaged tissue. However, it appears that the M2 phase is an acquired state that plays a key role in the regenerative phase. One role for M2 macrophages is to secrete signals that stop the pro-inflammatory M1 phase through the release of many factors such as TGF-B and IL10 [107, 108]. However, this regenerative phase depends on whether the initial injury persists or not. When there are chronic injury signals, M2 macrophages can instead activate and exacerbate fibrosis [103, 109]. Additionally, comparisons between the transcriptomes of medaka and zebrafish macrophages showed the changes in gene expression profiles were similar, however the medaka profiles were less dynamic and consequently there was a reduced and delayed inflammation following injury. This again suggests that medaka macrophages still possess the ability to facilitate regeneration but the signal is not potent enough to induce this phase. Especially since exogenous activation of Toll-like receptors agonists (which elicits the acceleration of macrophage recruitment and neutrophil clearance) in injured medaka hearts boosted regeneration [3].

Taken together, it appears that medaka have lost the ability to regenerate their hearts through adaptations in their inflammatory response. These adaptations include less dynamic macrophages, delayed neutrophil clearance and delayed macrophage recruitment to the injury site [3]. This dampening of inflammation follows the theory that there is an inverse relationship between organ and limb regenerative capacity and the strength of the inflammatory response within the innate immune system [110-112]. However, it remains unclear why medaka fish have evolved an altered innate immune system. A distinct difference from the regenerative zebrafish is that medaka stay longer in their chorions [113], thereby providing medaka embryos with a safe environment. Potentially, the prolonged protection by the chorion reduced the need for a strong injury response during early development. However, whether this resulted in the evolutionary adaptations seen in the medaka innate immune system, remains unclear.

\section{Regeneration trait: modifying DNA content- polyploidy and polynucleation}

Cells can exist with a varying amount of DNA material in the form of polyploidy (more than two sets of chromosomes per nuclei) and polynucleation (more than one nucleus). This phenomenon arises through the fusion of neighbouring cells or resulting from complete DNA replication without mitosis or cytokinesis (endoreplication) [114]. For example, adult hepatocytes, skeletal muscle, certain cell types in the lung, kidney, pancreas and CMs are typically polyploid [114]. In CMs, ploidy differs between species. CMs of non-mammalian species such as fish, amphibians and reptiles are mainly mononucleated 
and diploid. While at least $50 \%$ of the CMs in mammals such as humans, rodents, bats, livestock and even whales are multinucleated and polyploid [115]. Initially, mammalian CMs are predominately mononucleated and diploid, but this changes after birth. In the mouse heart, CM polyploidization commences during the first week after birth $[102,116]$, after the loss of the cardiac regenerative potential period $[14,16]$, while in humans, the persistence of polyploidy is maintained throughout life [101]. It is unclear why humans and mouse whom are both poor regenerators evolved to have different compositions of DNA content in their CMs (multinucleated vs polyploidy, respectively). However, we have grouped these two events into one trait of modifying DNA content since as we will further discuss, the same end result in both contexts appears to modulate cardiac regeneration capacity.

The relation between ploidy and regenerative capacity of the heart was established in a survey of more than 120 genetically defined inbred mouse strains with variation in CMs ploidy. Furthermore, genetic experiments in mice confirmed such a correlation between the percentage of mononucleated CMs and regenerative capacity [91, 92]. In zebrafish, a direct correlation between ploidy and regenerative capacity was also established. The majority of CMs in zebrafish are mononucleated and diploid [90, 117], however increasing the percentage of polyploid CMs impaired regenerative capacity of the heart [90]. While in zebrafish and mice, a correlation between $\mathrm{CM}$ mononucleation and regenerative capacity was established, this correlation seems less clear in the porcine heart. In the porcine heart, polyploidization with multinucleation occurs over a 2-month period while loss of heart regeneration potential occurs at P3 [118].

The benefit of polyploidization is not well understood. One idea is that the polyploidy state prevents DNA damage [119] since the polyploidy state in hepatocytes have been shown to play a tumour-suppressive role in the liver [120]. Therefore, the stabilization of the nucleus facilitates the longevity of the organ and this trade-off for regenerative potential may allow cells to survive and maintain function. This would be important in the context of the heart as its function is regular contractions and unstable cells within the heart would compromise this role. Another explanation would be to support organ growth. It is theorized that the increase of polyploidy can support the growth of the cell via increased gene expression and therefore maintain higher cellular activity [121]. In the case of CMs, a larger cell would allow increased metabolic rates for energy production to support the metabolically intensive activity of contractions [122].

Taken together, mammals like mice and humans have adapted the nuclear content of cardiomyocytes, favouring multinucleated or polyploidy nuclei, respectively. While these adaptations might have resulted in distinct benefits such as a reduced risk of DNA-damage and potent regulation of cellular growth, it also limits cardiomyocyte proliferation and therefore heart regeneration.

\section{Regeneration trait: energy consumption}

Endothermal animals are able to self-regulate their body temperature as opposed to ectothermic animals that acquire the temperature of their environment. Thus, far adult heart regeneration capacity has only been reported in ectothermic fish and amphibians and not in endothermic birds or mammals and this may be attributed to difference in energy metabolism as endotherms have a higher resting rate metabolism [123]. This increase in resting rate metabolism is due to elevated aerobic metabolism, which is a very efficient process of energy production. Aerobic metabolism requires oxidative phosphorylation (OXPHOS) that occurs inside mitochondria. When less oxygen is available to cells, they can revert to glycolysis and lactate fermentation for energy metabolism, which generates lactate. While OXPHOS is much more efficient in producing energy as in ATP, it leads to the generation of reactive oxygen species (ROS), which can cause DNA damage. While the adult heart mainly utilizes fatty acids and OXPHOS for the generation of ATP, during mammalian development the foetus grows in an oxygen poor environment and the heart mainly utilizes glucose and glycolysis for energy metabolism. The transition from a low oxygen environment in utero, to an oxygen rich environment after birth coincidences with a shift in energy metabolism of cardiomyocytes from glycolysis towards the oxidation of fatty acids and OXPHOS [124, 125], 126. This also coincides with an increase in ROS production, DNA damage and a strong reduction in cardiomyocyte proliferation [126]. The increase in OXPHOS activity after birth impairs CM proliferation as reducing environmental oxygen after birth, inhibiting fatty acid utilization or promoting ROS scavenging prolongs the proliferative window of cardiomyocytes [126, 127].

Besides the negative effects of OXPHOS and ROS production on $\mathrm{CM}$ proliferation, $\mathrm{CM}$ require glycolysis and lactate fermentation for efficient proliferation. In the regenerating zebrafish heart proliferating CMs in the border zone shift their energy metabolism from OXPHOS to glycolysis and when this is prevented CM proliferation and regeneration is impaired $[88,89]$. Conversely, stimulating glycolysis promotes CM proliferation [89]. The regulation of energy metabolism is highly complex and involves many pathways. Neuregulin 1 (Nrg1) is an agonist for the Epidermal Growth Factor Receptor Tyrosine Kinase family which includes ErbB1, 2, 3 and 4 [128]. There are several indications that in the heart this pathway plays an important role in controlling $\mathrm{CM}$ proliferation through regulation of energy metabolism. First, during development, $\mathrm{Nrg} 1 / \mathrm{ErbB} 2$ signalling is important for cardiac development as knock out mice for these 
genes and zebrafish erbb2 mutants are embryonically lethal as a result of a thinner myocardium due to reduced CM proliferation [129-134]. Second, CM-specific expression of a constitutively active form of ErbB2 (caErbB2) results in cardiomegaly (large hearts) via increased CM proliferation [131]. In addition, when $\mathrm{Nrg} 1$ is overexpressed specifically in zebrafish CMs in an absence of injury, the fish also develop cardiomegaly by enhanced CM proliferation [135]. Third, activation of $\mathrm{Nrg} 1 / \mathrm{ErbB} 2$ signalling in mouse and zebrafish hearts stimulates glycolysis in embryonic and adult CMs $[88,136]$. In the context of heart regeneration, $\mathrm{Nrg} 1$ expression is induced in the zebrafish heart upon injury, which again is required for the activation of glycolysis and induction of CM proliferation [88, 135].

Why is a shift from fatty acid oxidation to glycolysis important for $\mathrm{CM}$ proliferation? One could argue that since mitochondrial OXPHOS generates ROS which is capable of inducing a DNA damage response and cell cycle arrest [126], 137, it may be better for the proliferative cell to revert to a lower energy producing state to reduce ROS production. Another argument could be that during proliferation, since there is a disassembly of the contractile apparatus $[88,96]$, the high energy consumption is not needed as compared to a functionally contracting $\mathrm{CM}$ and therefore the more inefficient energy producing pathway would suffice. Finally, intermediate metabolites produced by aerobic glycolysis may be converted into precursors for the biosynthesis of amino acids and nucleotides that are essential for cell proliferation and growth $[137,138]$. In addition, there have been reports that components of the glycolytic pathway directly interact with cell cycle regulators, which is independent from their catalytic activity, $[139,140]$ and therefore this pathway may be required to activate the proliferation programme.

The trade-off between regenerative potential and metabolism can also be seen in Mexican cavefish. This teleost species (Astyanax mexicanus) is a single species comprising of two populations. A cave-dwelling (Pachón) and surface-dwelling population. About 1.5 million years ago, these two populations diverged due to the changing environment of the Mexican rivers and caves and resulted in the Pachón population losing certain features such as their eyes and pigments [141], and instead acquire new traits such as highly sensitive taste buds and lateral line neurons for navigating in the dark [141]. Interestingly, due to the food scarcity within the caves, the Pachón have adapted by changing its glucose metabolism [142, 143]. In particular, RNA-seq between these fish populations indicate a downregulation of glycolysis-related genes [5]. Moreover, the Pachón population cannot regenerate its heart following injury when compared to their surfacing dwelling counterparts [5]. While yet to be tested, if the surface dwelling fish also require a glycolytic switch in their CMs to facilitate $\mathrm{CM}$ proliferation, this would indicate the regeneration trade-off in the Pachón population may be beneficial for other functions that allow this species to survive.

Metabolism and endothermy are highly linked since endotherms have higher metabolic rates compared to ectotherms. The origin of endothermy in birds and mammals is a controversial topic in evolutionary biology. Several hypotheses have been proposed to explain its evolutionary origin of which the aerobic capacity model received most attention [123, 144, 145]. Physiological studies indicate that resting and maximal rate metabolism are linked so that one cannot increase without the other. The aerobic capacity model proposes that an increase in resting rate metabolism supported an increase in maximal rate metabolism to allow sustained muscle activities. High maximal oxygen consumption rates allow sustained workloads by aerobic metabolism, which is beneficial for many activities such as capturing prey or sustained flight. In addition, the increase in resting rate metabolism facilitated the regulation of body temperature. The increase in resting rate metabolism by mitochondrial OXPHOS requires higher oxygen consumption, which may have resulted in adaptations such as a more efficient ventilation system and an increase in blood circulation. Numerous adaptations seen in hearts of mammals and birds, such as separation of the chambers and increased wall thickness, accommodate a more efficient oxygen transportation to all tissues [146]. Therefore, heart regeneration, which depends on the ability of CMs to switch energy metabolism from a very efficient fatty acid oxidation to a more inefficient glucose metabolism by glycolysis and lactate fermentation, may have been a trade-off for an increase in energy demands in endotherms. This may not be restricted to only heart regeneration since a comparable metabolic switch towards glycolysis was also observed during appendage regeneration [147].

The higher availability of oxygen for energy production could in part be due to the aquatic to terrestrial transition which began approximately 500 to 400 million years ago [148]. Some possible reasons for this transition could be due to animals living during the Ordovician-Silurian extinction event, a period of marine $\mathrm{O}_{2}$ deprivation [148]. Another reason an increase in atmospheric $\mathrm{O}_{2}$ concentration allowed for bigger animals to form and therefore gain a competitive advantage against potential predators [149]. The link between animal size and atmospheric $\mathrm{O}_{2}$ concentration is evident as giant animals became extinct when $\mathrm{O}_{2}$ concentrations reduced $[150,151]$. While it is tempting to suggest that the transition from aquatic to terrestrial environment for vertebrates caused the loss of the regenerative trait, it is possible this trait developed independently of this transition.

\section{Inducing regenerative traits in species with a poor regenerative capacity}

All vertebrates can regenerate to an extent, the difference lies in the capacity of the particular organ. Thus, one could 
view regeneration as a dormant process in organs that do not regenerate and manipulating this process can reactivate the organ's ability to proliferate. Following this reasoning, there have been attempts to boost $\mathrm{CM}$ proliferation in mammalian hearts. The modulation of both Hippo and ErbB2 signalling and most recently the interaction between these two pathways can robustly induce CM proliferation and regeneration following injury [131, 152-154]. In all cases, when proliferation is induced, a number of cellular and molecular processes are activated that involve some of the above-mentioned regenerative traits. For example, mononucleated CMs preferentially undergo proliferation compared to binucleated CMs [131, 155]. Meanwhile both zebrafish hearts via Nrg1 overexpression and mouse hearts via caErbB2 overexpression switch in metabolism towards glycolysis, which is required for $\mathrm{CM}$ proliferation [88]. In addition, ectopic expression of $\mathrm{Pkm} 2$, an isoenzyme of the glycolytic pyruvate kinase, in injured mouse hearts induces CM proliferation and restored cardiac function [156]. While the induction of the Nrg1/Erbb2 pathway appears to directly affect certain regeneration associated traits (e.g., metabolic reprogramming), it appears it can completely bypass others (e.g., polyploidy) by focussing on a specific subset of CMs (mononuclear, diploid). Understanding the factors that can overcome the regenerative block by examining interactions between pro-regenerative pathways (e.g., Nrg1/Erbb2 signalling) with the traits and processes affecting regenerative capacity, will help us develop novel methods of inducing CM proliferation and subsequent cardiac regeneration in mammals.

\section{Concluding remarks}

Cardiac regeneration is a multimodal process that requires the precise regulation of numerous processes and cell types. It is unclear what the origin of cardiac regeneration is, but common features such as activation of CM proliferation suggest that it may have a common origin. How cardiac regeneration has been maintained or lost in specific animals is under extensive debate [1]. The loss of cardiac regenerative capacity can result from adaptations in any of the traits and processes described in this review, including the innnate immune system, nuclear organization and metabolism. The heterogeneous distribution of cardiac regenerative capacity throughout the animal kingdom might therefore be a direct consequence of the complexity of the regeneration process. Here, we have summarized several examples of species that might have lost cardiac regenerative capacity through adaptations in distinctly different traits. Therefore, we might consider cardiac regenerative capacity as "an evolutionary afterthought", only when no other traits take precedence, cardiac regeneration becomes an evolutionary priority to maintain, and this could be explained by either the pleiotropy or adaptive hypothesis [1]. In the pleiotropy scenario, regeneration would be retained because it is developmentally tightly controlled to other adaptations. Cavefish for example changed their metabolism to adapt to the scarce food availability and this metabolomic state is also linked to $\mathrm{CM}$ proliferation. The adaptive hypothesis predicts that a trait is actively being maintained during selection and regeneration would be viewed to being negatively selected over repair. In general, the relative body size in poor vs. robust cardiac regenerators is anticorrelated, thus the energy and mechanical requirements for the heart to properly function and sustain the body is much higher in bigger and poor regenerators. Therefore, the need to quickly repair the injury and maintain heart function is being selected over the more slower regeneration process. The energy required to regenerate could also be expensive since the CMs themselves undergo dramatic changes to proliferate and mature, compared to a more simpler repair process. Thus, repair may be favoured in non-cardiac regenerators to divert energy expenditure to other energy intensive processes/organs. Alternatively, a phylogenetic inertia scenario could describe regeneration as this theory predicts the traits are being maintained for historical reasons and confer no selective advantage or disadvantage, therefore this trait was not yet been eliminated from the collection of traits an animal has acquired for survival [1]. Comparative studies between species allow us to identify differences and similarities between species and better understanding of the traits and processes underlying or limiting cardiac regeneration in these different species could potentially help overcome the limited regenerative capacity in mammalian hearts.

Author contributions PDN and DEMB researched and drafted the manuscript. JB critically revised the work. All authors read and approved the final manuscript.

Funding P.D.N is supported by an EMBO Long Term Fellowship ALTF1129-2015, HFSPO Fellowship (LT001404/2017-L) and a NWO-ZonMW Veni Grant (016.186.017-3). D.E.M.B. is supported by the Dutch heart foundation as part of the COBRA $^{3}$ consortium (NHS 2013T091). Work in J.B.'s laboratory is supported by the Netherlands Cardiovascular Research Initiative: An initiative with support of the Dutch Heart Foundation and Hartekind, CVON2019-002 OUTREACH.

\section{Declarations}

Conflict of interest The authors declare that they have no competing interests.

Open Access This article is licensed under a Creative Commons Attribution 4.0 International License, which permits use, sharing, adaptation, distribution and reproduction in any medium or format, as long as you give appropriate credit to the original author(s) and the source, provide a link to the Creative Commons licence, and indicate if changes were made. The images or other third party material in this article are included in the article's Creative Commons licence, unless indicated otherwise in a credit line to the material. If material is not included in 
the article's Creative Commons licence and your intended use is not permitted by statutory regulation or exceeds the permitted use, you will need to obtain permission directly from the copyright holder. To view a copy of this licence, visit http://creativecommons.org/licenses/by/4.0/.

\section{References}

1. Bely AE, Nyberg KG (2010) Evolution of animal regeneration: re-emergence of a field. Trends Ecol Evol 25(3):161-170. https:// doi.org/10.1016/j.tree.2009.08.005

2. Forbes SJ, Rosenthal N (2014) Preparing the ground for tissue regeneration: from mechanism to therapy. Nat Med 20(8):857869. https://doi.org/10.1038/nm.3653

3. Lai SL, Marín-Juez R, Moura PL, Kuenne C, Lai JKH, Tsedeke AT, Guenther S, Looso M, Stainier DY (2017) Reciprocal analyses in zebrafish and medaka reveal that harnessing the immune response promotes cardiac regeneration. Elife. https://doi.org/10. 7554/eLife. 25605

4. Ito K, Morioka M, Kimura S, Tasaki M, Inohaya K, Kudo A (2014) Differential reparative phenotypes between zebrafish and medaka after cardiac injury. Dev Dyn 243(9):1106-1115. https:// doi.org/10.1002/dvdy.24154

5. Stockdale WT, Lemieux ME, Killen AC, Zhao J, Hu Z, Riepsaame J, Hamilton N, Kudoh T, Riley PR, van Aerle R, Yamamoto Y, Mommersteeg MTM (2018) Heart regeneration in the mexican cavefish. Cell Rep 25(8):1997-2007.e7. https://doi.org/ 10.1016/j.celrep.2018.10.072

6. Lafontant PJ, Burns AR, Grivas JA, Lesch MA, Lala TD, Reuter SP, Field LJ, Frounfelter TD (2012) The giant danio (D. aequipinnatus) as a model of cardiac remodeling and regeneration. Anat Rec (Hoboken) 295(2):234-248. https://doi.org/10. 1002/ar.21492

7. Grivas J, Haag M, Johnson A, Manalo T, Roell J, Das TL, Brown E, Burns AR, Lafontant PJ (2014) Cardiac repair and regenerative potential in the goldfish (Carassius auratus) heart. Comp Biochem Physiol C Toxicol Pharmacol 163:14-23. https://doi. org/10.1016/j.cbpc.2014.02.002

8. Laube F, Heister M, Scholz C, Borchardt T, Braun T (2006) Re-programming of newt cardiomyocytes is induced by tissue regeneration. J Cell Sci 119(Pt 22):4719-4729. https://doi.org/ $10.1242 /$ jcs. 03252

9. Oberpriller JO, Oberpriller JC (1974) Response of the adult newt ventricle to injury. J Exp Zool 187(2):249-253. https://doi.org/ 10.1002/jez.1401870208

10. Godwin JW, Debuque R, Salimova E, Rosenthal NA (2017) Heart regeneration in the salamander relies on macrophage-mediated control of fibroblast activation and the extracellular landscape. NPJ Regen Med. https://doi.org/10.1038/s41536-017-0027-y

11. Cano-Martínez A, Vargas-González A, Guarner-Lans V, PradoZayago E, León-Oleda M, Nieto-Lima B (2010) Functional and structural regeneration in the axolotl heart (Ambystoma mexicanum) after partial ventricular amputation. Arch Cardiol Mex 80(2):79-86

12. Vargas-González A, Prado-Zayago E, León-Olea M, GuarnerLans V, Cano-Martínez A (2005) Myocardial regeneration in Ambystoma mexicanum after surgical injury. Arch Cardiol Mex 75(3):21-29

13. Poss KD, Wilson LG, Keating MT (2002) Heart regeneration in zebrafish. Science 298(5601):2188-2190. https://doi.org/10. 1126/science. 1077857

14. Porrello ER, Mahmoud AI, Simpson E, Hill JA, Richardson JA, Olson EN, Sadek HA (2011) Transient regenerative potential of the neonatal mouse heart. Science 331(6020):1078-1080. https:// doi.org/10.1126/science. 1200708
15. Porrello ER, Mahmoud AI, Simpson E, Johnson BA, Grinsfelder D, Canseco D, Mammen PP, Rothermel BA, Olson EN, Sadek HA (2013) Regulation of neonatal and adult mammalian heart regeneration by the miR-15 family. Proc Natl Acad Sci USA 110(1):187-192. https://doi.org/10.1073/pnas.1208863110

16. Notari M, Ventura-Rubio A, Bedford-Guaus SJ, Jorba I, Mulero L, Navajas D, Martí M, Raya Á (2018) The local microenvironment limits the regenerative potential of the mouse neonatal heart. Sci Adv 4(5):eaao5553. https://doi.org/10.1126/sciadv. aao5553

17. Zhu W, Zhang E, Zhao M, Chong Z, Fan C, Tang Y, Hunter JD, Borovjagin AV, Walcott GP, Chen JY, Qin G, Zhang J (2018) Regenerative potential of neonatal porcine hearts. Circulation 138(24):2809-2816. https://doi.org/10.1161/circulationaha. 118.034886

18. Ye L, D'Agostino G, Loo SJ, Wang CX, Su LP, Tan SH, Tee GZ, Pua CJ, Pena EM, Cheng RB, Chen WC, Abdurrachim D, Lalic J, Tan RS, Lee TH, Zhang J, Cook SA (2018) Early regenerative capacity in the porcine heart. Circulation 138(24):2798-2808. https://doi.org/10.1161/circulationaha. 117.031542

19. Haubner BJ, Schneider J, Schweigmann U, Schuetz T, Dichtl W, Velik-Salchner C, Stein JI, Penninger JM (2016) Functional recovery of a human neonatal heart after severe myocardial infarction. Circ Res 118(2):216-221. https://doi.org/10.1161/ circresaha.115.307017

20. Papneja K, Chan AK, Mondal TK, Paes B (2017) Myocardial infarction in neonates: a review of an entity with significant morbidity and mortality. Pediatr Cardiol 38(3):427-441. https://doi. org/10.1007/s00246-016-1556-7

21. Yang F, Liu YH, Yang XP, Xu J, Kapke A, Carretero OA (2002) Myocardial infarction and cardiac remodelling in mice. Exp Physiol 87(5):547-555. https://doi.org/10.1113/eph8702385

22. Cannon RO 3rd, Butany JW, McManus BM, Speir E, Kravitz AB, Bolli R, Ferrans VJ (1983) Early degradation of collagen after acute myocardial infarction in the rat. Am J Cardiol 52(3):390395. https://doi.org/10.1016/0002-9149(83)90145-5

23. Whittaker P, Boughner DR, Kloner RA (1991) Role of collagen in acute myocardial infarct expansion. Circulation 84(5):21232134. https://doi.org/10.1161/01.cir.84.5.2123

24. Dobaczewski M, Bujak M, Zymek P, Ren G, Entman ML, Frangogiannis NG (2006) Extracellular matrix remodeling in canine and mouse myocardial infarcts. Cell Tissue Res 324(3):475-488. https://doi.org/10.1007/s00441-005-0144-6

25. Brown LF, Yeo K, Berse B, Yeo TK, Senger DR, Dvorak HF, Van De Water L (1992) Expression of vascular permeability factor (vascular endothelial growth factor) by epidermal keratinocytes during wound healing. J Exp Med 176(5):1375-1379

26. Brown LF, Dubin D, Lavigne L, Logan B, Dvorak HF, Van de Water L (1993) Macrophages and fibroblasts express embryonic fibronectins during cutaneous wound healing. Am J Pathol 142(3):793-801

27. Ulrich MM, Janssen AM, Daemen MJ, Rappaport L, Samuel JL, Contard F, Smits JF, Cleutjens JP (1997) Increased expression of fibronectin isoforms after myocardial infarction in rats. $\mathrm{J}$ Mol Cell Cardiol 29(9):2533-2543. https://doi.org/10.1006/jmcc. 1997.0486

28. Ignotz RA, Massagué J (1986) Transforming growth factorbeta stimulates the expression of fibronectin and collagen and their incorporation into the extracellular matrix. J Biol Chem 261(9):4337-4345

29. Cleutjens JP, Verluyten MJ, Smiths JF, Daemen MJ (1995) Collagen remodeling after myocardial infarction in the rat heart. Am J Pathol 147(2):325-338

30. Wei S, Chow LT, Shum IO, Qin L, Sanderson JE (1999) Left and right ventricular collagen type I/III ratios and remodeling 
post-myocardial infarction. J Card Fail 5(2):117-126. https://doi. org/10.1016/s1071-9164(99)90034-9

31. Baudino TA, Carver W, Giles W, Borg TK (2006) Cardiac fibroblasts: friend or foe? Am J Physiol Heart Circ Physiol 291(3):H1015-1026. https://doi.org/10.1152/ajpheart.00023. 2006

32. Travers JG, Kamal FA, Robbins J, Yutzey KE, Blaxall BC (2016) Cardiac fibrosis: the fibroblast awakens. Circ Res 118(6):10211040. https://doi.org/10.1161/circresaha.115.306565

33. Garcia-Puig A, Mosquera JL, Jiménez-Delgado S, García-Pastor C, Jorba I, Navajas D, Canals F, Raya A (2019) Proteomics analysis of extracellular matrix remodeling during zebrafish heart regeneration. Mol Cell Proteom 18(9):1745-1755. https://doi.org/10.1074/mcp.RA118.001193

34. Chablais F, Veit J, Rainer G, Jaźwińska A (2011) The zebrafish heart regenerates after cryoinjury-induced myocardial infarction. BMC Dev Biol 11:21. https://doi.org/10.1186/ 1471-213x-11-21

35. Münch J, Grivas D, González-Rajal Á, Torregrosa-Carrión R, de la Pompa JL (2017) Notch signalling restricts inflammation and serpine1 expression in the dynamic endocardium of the regenerating zebrafish heart. Development 144(8):1425-1440. https:// doi.org/10.1242/dev.143362

36. Chablais F, Jazwinska A (2012) The regenerative capacity of the zebrafish heart is dependent on TGF $\beta$ signaling. Development 139(11):1921-1930. https://doi.org/10.1242/dev.078543

37. Lepilina A, Coon AN, Kikuchi K, Holdway JE, Roberts RW, Burns CG, Poss KD (2006) A dynamic epicardial injury response supports progenitor cell activity during zebrafish heart regeneration. Cell 127(3):607-619. https://doi.org/10.1016/j.cell.2006.08. 052

38. Sánchez-Iranzo H, Galardi-Castilla M, Sanz-Morejón A, González-Rosa JM, Costa R, Ernst A, Sainz de Aja J, Langa X, Mercader N (2018) Transient fibrosis resolves via fibroblast inactivation in the regenerating zebrafish heart. Proc Natl Acad Sci USA 115(16):4188-4193. https://doi.org/10.1073/pnas.17167 13115

39. Gamba L, Amin-Javaheri A, Kim J, Warburton D, Lien CL (2017) Collagenolytic activity is associated with scar resolution in zebrafish hearts after cryoinjury. J Cardiovasc Dev Dis. https:// doi.org/10.3390/jcdd4010002

40. Xu S, Webb SE, Lau TCK, Cheng SH (2018) Matrix metalloproteinases (MMPs) mediate leukocyte recruitment during the inflammatory phase of zebrafish heart regeneration. Sci Rep 8(1):7199. https://doi.org/10.1038/s41598-018-25490-w

41. Bassat E, Mutlak YE, Genzelinakh A, Shadrin IY, Baruch Umansky K, Yifa O, Kain D, Rajchman D, Leach J, Riabov Bassat D, Udi Y, Sarig R, Sagi I, Martin JF, Bursac N, Cohen S, Tzahor E (2017) The extracellular matrix protein agrin promotes heart regeneration in mice. Nature 547(7662):179-184. https://doi.org/ 10.1038 /nature22978

42. Baehr A, Umansky KB, Bassat E, Jurisch V, Klett K, Bozoglu T, Hornaschewitz N, Solyanik O, Kain D, Ferraro B, CohenRabi R, Krane M, Cyran C, Soehnlein O, Laugwitz KL, Hinkel R, Kupatt C, Tzahor E (2020) Agrin promotes coordinated therapeutic processes leading to improved cardiac repair in pigs. Circulation 142(9):868-881. https://doi.org/10.1161/circulatio naha.119.045116

43. Chen WC, Wang Z, Missinato MA, Park DW, Long DW, Liu HJ, Zeng X, Yates NA, Kim K, Wang Y (2016) Decellularized zebrafish cardiac extracellular matrix induces mammalian heart regeneration. Sci Adv 2(11):e1600844. https://doi.org/10.1126/ sciadv. 1600844

44. Wang Z, Long DW, Huang Y, Chen WCW, Kim K, Wang Y (2019) Decellularized neonatal cardiac extracellular matrix prevents widespread ventricular remodeling in adult mammals after myocardial infarction. Acta Biomater 87:140-151. https://doi. org/10.1016/j.actbio.2019.01.062

45. Marro J, Pfefferli C, de Preux Charles A-S, Bise T, Jaźwińska A (2016) Collagen XII contributes to epicardial and connective tissues in the zebrafish heart during ontogenesis and regeneration. PLoS One 11(10):e0165497. https://doi.org/10.1371/journ al.pone.0165497

46. Möllmert S, Kharlamova MA, Hoche T, Taubenberger AV, Abuhattum S, Kuscha V, Kurth T, Brand M, Guck J (2020) Zebrafish spinal cord repair is accompanied by transient tissue stiffening. Biophys J 118(2):448-463. https://doi.org/10.1016/j.bpj.2019. 10.044

47. Burnside ER, Bradbury EJ (2014) Manipulating the extracellular matrix and its role in brain and spinal cord plasticity and repair. Neuropathol Appl Neurobiol 40(1):26-59. https://doi.org/10. 1111/nan.12114

48. Kanisicak O, Khalil H, Ivey MJ, Karch J, Maliken BD, Correll RN, Brody MJ, Lin SCJ, Aronow BJ, Tallquist MD, Molkentin JD (2016) Genetic lineage tracing defines myofibroblast origin and function in the injured heart. Nat Commun 7(1):1-14

49. Thavapalachandran S, Grieve SM, Hume RD, Le TYL, Raguram K, Hudson JE, Pouliopoulos J, Figtree GA, Dye RP, Barry AM, Brown P, Lu J, Coffey S, Kesteven SH, Mills RJ, Rashid FN, Taran E, Kovoor P, Thomas L, Denniss AR, Kizana E, Asli NS, Xaymardan M, Feneley MP, Graham RM, Harvey RP, Chong JJH (2020) Platelet-derived growth factor-AB improves scar mechanics and vascularity after myocardial infarction. Sci Transl Med. https://doi.org/10.1126/scitranslmed.aay2140

50. Yokota T, McCourt J, Ma F, Ren S, Li S, Kim TH, Kurmangaliyev YZ, Nasiri R, Ahadian S, Nguyen T, Tan XHM, Zhou Y, Wu R, Rodriguez A, Cohn W, Wang Y, Whitelegge J, Ryazantsev S, Khademhosseini A, Teitell MA, Chiou PY, Birk DE, Rowat AC, Crosbie RH, Pellegrini M, Seldin M, Lusis AJ, Deb A (2020) Type $\mathrm{V}$ collagen in scar tissue regulates the size of scar after heart injury. Cell 182(3):545-562.e523. https://doi.org/10.1016/j. cell.2020.06.030

51. Leid J, Carrelha J, Boukarabila H, Epelman S, Jacobsen SEW, Lavine KJ (2016) Primitive embryonic macrophages are required for coronary development and maturation. Circ Res 118(10):1498-1511. https://doi.org/10.1161/CIRCRESAHA. 115.308270

52. Lavine KJ, Epelman S, Uchida K, Weber KJ, Nichols CG, Schilling JD, Ornitz DM, Randolph GJ, Mann DL (2014) Distinct macrophage lineages contribute to disparate patterns of cardiac recovery and remodeling in the neonatal and adult heart. Proc Natl Acad Sci USA 111(45):16029-16034. https://doi.org/10. 1073/pnas. 1406508111

53. Yan X, Anzai A, Katsumata Y, Matsuhashi T, Ito K, Endo J, Yamamoto T, Takeshima A, Shinmura K, Shen W, Fukuda K, Sano M (2013) Temporal dynamics of cardiac immune cell accumulation following acute myocardial infarction. J Mol Cell Cardiol 62:24-35. https://doi.org/10.1016/j.yjmcc.2013.04.023

54. Rausch PG, Moore TG (1975) Granule enzymes of polymorphonuclear neutrophils: a phylogenetic comparison. Blood 46(6):913-919

55. Natarajan N, Abbas Y, Bryant DM, Gonzalez-Rosa JM, Sharpe M, Uygur A, Cocco-Delgado LH, Ho NN, Gerard NP, Gerard CJ, MacRae CA, Burns CE, Burns CG, Whited JL, Lee RT (2018) Complement receptor C5aR1 plays an evolutionarily conserved role in successful cardiac regeneration. Circulation 137(20):2152-2165. https://doi.org/10.1161/circulationaha.117. 030801

56. Wysoczynski M, Solanki M, Borkowska S, van Hoose P, Brittian KR, Prabhu SD, Ratajczak MZ, Rokosh G (2014) Complement component 3 is necessary to preserve myocardium and 
myocardial function in chronic myocardial infarction. Stem Cells 32(9):2502-2515. https://doi.org/10.1002/stem.1743

57. Horckmans M, Ring L, Duchene J, Santovito D, Schloss MJ, Drechsler M, Weber C, Soehnlein O, Steffens S (2017) Neutrophils orchestrate post-myocardial infarction healing by polarizing macrophages towards a reparative phenotype. Eur Heart $\mathbf{J}$ 38(3):187-197. https://doi.org/10.1093/eurheartj/ehw002

58. Lindsey ML (2018) Assigning matrix metalloproteinase roles in ischaemic cardiac remodelling. Nat Rev Cardiol 15(8):471-479. https://doi.org/10.1038/s41569-018-0022-Z

59. Chen B, Huang S, Su Y, Wu YJ, Hanna A, Brickshawana A, Graff J, Frangogiannis NG (2019) Macrophage smad3 protects the infarcted heart, stimulating phagocytosis and regulating inflammation. Circ Res 125(1):55-70. https://doi.org/10.1161/ circresaha.119.315069

60. Wang Z, Cui M, Shah AM, Ye W, Tan W, Min YL, Botten GA, Shelton JM, Liu N, Bassel-Duby R, Olson EN (2019) Mechanistic basis of neonatal heart regeneration revealed by transcriptome and histone modification profiling. Proc Natl Acad Sci USA 116(37):18455-18465. https://doi.org/10.1073/pnas.1905824116

61. Xu S, Xie F, Tian L, Manno SH, Manno FAM 3rd, Cheng SH (2019) Prolonged neutrophil retention in the wound impairs zebrafish heart regeneration after cryoinjury. Fish Shellfish Immunol 94:447-454. https://doi.org/10.1016/j.fsi.2019.09.030

62. Nguyen-Chi M, Laplace-Builhe B, Travnickova J, Luz-Crawford P, Tejedor G, Phan QT, Duroux-Richard I, Levraud JP, Kissa K, Lutfalla G, Jorgensen C, Djouad F (2015) Identification of polarized macrophage subsets in zebrafish. Elife 4:e07288. https://doi. org/10.7554/eLife.07288

63. Sanz-Morejón A, García-Redondo AB, Reuter H, Marques IJ, Bates T, Galardi-Castilla M, Große A, Manig S, Langa X, Ernst A, Piragyte I, Botos MA, González-Rosa JM, Ruiz-Ortega M, Briones AM, Salaices M, Englert C, Mercader N (2019) Wilms tumor $1 \mathrm{~b}$ expression defines a pro-regenerative macrophage subtype and is required for organ regeneration in the zebrafish. Cell Rep 28(5):1296-1306.e1296. https://doi.org/10.1016/j.celrep. 2019.06.091

64. Hui SP, Sheng DZ, Sugimoto K, Gonzalez-Rajal A, Nakagawa S, Hesselson D, Kikuchi K (2017) Zebrafish regulatory $\mathrm{T}$ cells mediate organ-specific regenerative programs. Dev Cell 43(6):659-672.e655. https://doi.org/10.1016/j.devcel.2017.11. 010

65. Li J, Brown LF, Hibberd MG, Grossman JD, Morgan JP, Simons M (1996) VEGF, flk-1, and flt-1 expression in a rat myocardial infarction model of angiogenesis. Am J Physiol 270(5 Pt 2):H1803-1811. https://doi.org/10.1152/ajpheart.1996.270.5. H1803

66. Lin YD, Luo CY, Hu YN, Yeh ML, Hsueh YC, Chang MY, Tsai DC, Wang JN, Tang MJ, Wei EI, Springer ML, Hsieh PC (2012) Instructive nanofiber scaffolds with VEGF create a microenvironment for arteriogenesis and cardiac repair. Sci Transl Med 4(146):146ra109. https://doi.org/10.1126/scitranslmed.3003841

67. Lee SH, Wolf PL, Escudero R, Deutsch R, Jamieson SW, Thistlethwaite PA (2000) Early expression of angiogenesis factors in acute myocardial ischemia and infarction. N Engl J Med 342(9):626-633. https://doi.org/10.1056/nejm200003023420904

68. Kobayashi K, Maeda K, Takefuji M, Kikuchi R, Morishita Y, Hirashima M, Murohara T (2017) Dynamics of angiogenesis in ischemic areas of the infarcted heart. Sci Rep 7(1):7156. https:// doi.org/10.1038/s41598-017-07524-x

69. Moccetti F, Brown E, Xie A, Packwood W, Qi Y, Ruggeri Z, Shentu W, Chen J, López JA, Lindner JR (2018) Myocardial infarction produces sustained proinflammatory endothelial activation in remote arteries. J Am Coll Cardiol 72(9):1015-1026. https://doi.org/10.1016/j.jacc.2018.06.044
70. Ren G, Michael LH, Entman ML, Frangogiannis NG (2002) Morphological characteristics of the microvasculature in healing myocardial infarcts. J Histochem Cytochem 50(1):71-79. https:// doi.org/10.1177/002215540205000108

71. Zymek P, Bujak M, Chatila K, Cieslak A, Thakker G, Entman ML, Frangogiannis NG (2006) The role of platelet-derived growth factor signaling in healing myocardial infarcts. J Am Coll Cardiol 48(11):2315-2323. https://doi.org/10.1016/j.jacc.2006. 07.060

72. Chen CW, Okada M, Proto JD, Gao X, Sekiya N, Beckman SA, Corselli M, Crisan M, Saparov A, Tobita K, Péault B, Huard J (2013) Human pericytes for ischemic heart repair. Stem Cells 31(2):305-316. https://doi.org/10.1002/stem.1285

73. Katare R, Riu F, Mitchell K, Gubernator M, Campagnolo P, Cui Y, Fortunato O, Avolio E, Cesselli D, Beltrami AP, Angelini G, Emanueli C, Madeddu P (2011) Transplantation of human pericyte progenitor cells improves the repair of infarcted heart through activation of an angiogenic program involving microRNA-132. Circ Res 109(8):894-906. https://doi.org/10.1161/ circresaha.111.251546

74. Nelissen-Vrancken HJ, Debets JJ, Snoeckx LH, Daemen MJ, Smits JF (1996) Time-related normalization of maximal coronary flow in isolated perfused hearts of rats with myocardial infarction. Circulation 93(2):349-355. https://doi.org/10.1161/ 01.cir.93.2.349

75. Desmoulière A, Redard M, Darby I, Gabbiani G (1995) Apoptosis mediates the decrease in cellularity during the transition between granulation tissue and scar. Am J Pathol 146(1):56-66

76. Marín-Juez R, Marass M, Gauvrit S, Rossi A, Lai SL, Materna SC, Black BL, Stainier DY (2016) Fast revascularization of the injured area is essential to support zebrafish heart regeneration. Proc Natl Acad Sci USA 113(40):11237-11242. https://doi.org/ 10.1073/pnas.1605431113

77. Vivien CJ, Pichol-Thievend C, Sim CB, Smith JB, Bower NI, Hogan BM, Hudson JE, Francois M, Porrello ER (2019) Vegfc/ddependent regulation of the lymphatic vasculature during cardiac regeneration is influenced by injury context. NPJ Regen Med 4:18. https://doi.org/10.1038/s41536-019-0079-2

78. Harrison MR, Feng X, Mo G, Aguayo A, Villafuerte J, Yoshida T, Pearson CA, Schulte-Merker S, Lien CL (2019) Late developing cardiac lymphatic vasculature supports adult zebrafish heart function and regeneration. Elife. https://doi.org/10.7554/eLife. 42762

79. Bergmann O, Bhardwaj RD, Bernard S, Zdunek S, Barnabé-Heider F, Walsh S, Zupicich J, Alkass K, Buchholz BA, Druid H, Jovinge S, Frisén J (2009) Evidence for cardiomyocyte renewal in humans. Science 324(5923):98-102. https://doi.org/10.1126/ science. 1164680

80. Senyo SE, Steinhauser ML, Pizzimenti CL, Yang VK, Cai L, Wang M, Wu TD, Guerquin-Kern JL, Lechene CP, Lee RT (2013) Mammalian heart renewal by pre-existing cardiomyocytes. Nature 493(7432):433-436. https://doi.org/10.1038/natur e11682

81. Soonpaa MH, Field LJ (1997) Assessment of cardiomyocyte DNA synthesis in normal and injured adult mouse hearts. Am J Physiol 272(1 Pt 2):H220-226. https://doi.org/10.1152/ajpheart. 1997.272.1.H220

82. Dispersyn GD, Mesotten L, Meuris B, Maes A, Mortelmans L, Flameng W, Ramaekers F, Borgers M (2002) Dissociation of cardiomyocyte apoptosis and dedifferentiation in infarct border zones. Eur Heart J 23(11):849-857. https://doi.org/10.1053/euhj. 2001.2963

83. Sharov VG, Sabbah HN, Ali AS, Shimoyama H, Lesch M, Goldstein $S$ (1997) Abnormalities of cardiocytes in regions bordering 
fibrous scars of dogs with heart failure. Int J Cardiol 60(3):273279. https://doi.org/10.1016/s0167-5273(97)00117-4

84. van Duijvenboden K, de Bakker DEM, Man JCK, Janssen R, Günthel M, Hill MC, Hooijkaas IB, van der Made I, van der Kraak PH, Vink A, Creemers EE, Martin JF, Barnett P, Bakkers J, Christoffels VM (2019) Conserved NPPB+ border zone switches from MEF2- to AP-1-driven gene program. Circulation 140(10):864-879. https://doi.org/10.1161/circulationaha.118. 038944

85. Kikuchi K, Holdway JE, Werdich AA, Anderson RM, Fang Y, Egnaczyk GF, Evans T, Macrae CA, Stainier DY, Poss KD (2010) Primary contribution to zebrafish heart regeneration by gata4(+) cardiomyocytes. Nature 464(7288):601-605. https:// doi.org/10.1038/nature08804

86. Jopling C, Sleep E, Raya M, Martí M, Raya A, Izpisúa Belmonte JC (2010) Zebrafish heart regeneration occurs by cardiomyocyte dedifferentiation and proliferation. Nature 464(7288):606-609. https://doi.org/10.1038/nature08899

87. Beisaw A, Kuenne C, Guenther S, Dallmann J, Wu CC, Bentsen M, Looso M, Stainier DYR (2020) AP-1 contributes to chromatin accessibility to promote sarcomere disassembly and cardiomyocyte protrusion during zebrafish heart regeneration. Circ Res 126(12):1760-1778. https://doi.org/10.1161/circresaha.119. 316167

88. Honkoop H, de Bakker DE, Aharonov A, Kruse F, Shakked A, Nguyen PD, de Heus C, Garric L, Muraro MJ, Shoffner A, Tessadori F, Peterson JC, Noort W, Bertozzi A, Weidinger G, Posthuma G, Grün D, van der Laarse WJ, Klumperman J, Jaspers RT, Poss KD, van Oudenaarden A, Tzahor E, Bakkers J (2019) Single-cell analysis uncovers that metabolic reprogramming by ErbB2 signaling is essential for cardiomyocyte proliferation in the regenerating heart. Elife. https://doi.org/10.7554/eLife.50163

89. Fukuda R, Marín-Juez R, El-Sammak H, Beisaw A, Ramadass R, Kuenne C, Guenther S, Konzer A, Bhagwat AM, Graumann J, Stainier DY (2020) Stimulation of glycolysis promotes cardiomyocyte proliferation after injury in adult zebrafish. EMBO Rep 21(8):e49752. https://doi.org/10.15252/embr.201949752

90. González-Rosa JM, Sharpe M, Field D, Soonpaa MH, Field LJ, Burns CE, Burns CG (2018) Myocardial polyploidization creates a barrier to heart regeneration in zebrafish. Dev Cell 44(4):433446.e437. https://doi.org/10.1016/j.devcel.2018.01.021

91. Patterson M, Barske L, Van Handel B, Rau CD, Gan P, Sharma A, Parikh S, Denholtz M, Huang Y, Yamaguchi Y, Shen H, Allayee H, Crump JG, Force TI, Lien CL, Makita T, Lusis AJ, Kumar SR, Sucov HM (2017) Frequency of mononuclear diploid cardiomyocytes underlies natural variation in heart regeneration. Nat Genet 49(9):1346-1353. https://doi.org/10.1038/ng.3929

92. Windmueller R, Leach JP, Babu A, Zhou S, Morley MP, Wakabayashi A, Petrenko NB, Viatour P, Morrisey EE (2020) Direct comparison of mononucleated and binucleated cardiomyocytes reveals molecular mechanisms underlying distinct proliferative competencies. Cell Rep 30(9):3105-3116.e3104. https://doi.org/ 10.1016/j.celrep.2020.02.034

93. Wang W, Hu CK, Zeng A, Alegre D, Hu D, Gotting K, Ortega Granillo A, Wang Y, Robb S, Schnittker R, Zhang S, Alegre D, Li H, Ross E, Zhang N, Brunet A, Sánchez Alvarado A (2020) Changes in regeneration-responsive enhancers shape regenerative capacities in vertebrates. Science. https://doi.org/10.1126/scien ce.aaz3090

94. Kang J, Hu J, Karra R, Dickson AL, Tornini VA, Nachtrab G, Gemberling M, Goldman JA, Black BL, Poss KD (2016) Modulation of tissue repair by regeneration enhancer elements. Nature 532(7598):201-206. https://doi.org/10.1038/nature17644

95. Goldman JA, Kuzu G, Lee N, Karasik J, Gemberling M, Foglia MJ, Karra R, Dickson AL, Sun F, Tolstorukov MY, Poss KD (2017) Resolving heart regeneration by replacement histone profiling. Dev Cell 40(4):392-404.e395. https://doi.org/10. 1016/j.devcel.2017.01.013

96. Wu CC, Kruse F, Vasudevarao MD, Junker JP, Zebrowski DC, Fischer K, Noël ES, Grün D, Berezikov E, Engel FB, van Oudenaarden A, Weidinger G, Bakkers J (2016) Spatially resolved genome-wide transcriptional profiling identifies BMP signaling as essential regulator of zebrafish cardiomyocyte regeneration. Dev Cell 36(1):36-49. https://doi.org/10.1016/j.devcel.2015.12. 010

97. Bevan L, Lim ZW, Venkatesh B, Riley PR, Martin P, Richardson RJ (2020) Specific macrophage populations promote both cardiac scar deposition and subsequent resolution in adult zebrafish. Cardiovasc Res 116(7):1357-1371. https://doi.org/10.1093/cvr/ cvz221

98. de Preux Charles AS, Bise T, Baier F, Marro J, Jaźwińska A (2016) Distinct effects of inflammation on preconditioning and regeneration of the adult zebrafish heart. Open Biol. https://doi. org/10.1098/rsob.160102

99. Frangogiannis NG, Smith CW, Entman ML (2002) The inflammatory response in myocardial infarction. Cardiovase Res 53(1):31-47. https://doi.org/10.1016/s0008-6363(01)00434-5

100. Aurora AB, Porrello ER, Tan W, Mahmoud AI, Hill JA, Bassel-Duby R, Sadek HA, Olson EN (2014) Macrophages are required for neonatal heart regeneration. J Clin Invest 124(3):1382-1392. https://doi.org/10.1172/jci72181

101. Brodsky V, Sarkisov DS, Arefyeva AM, Panova NW, Gvasava IG (1994) Polyploidy in cardiac myocytes of normal and hypertrophic human hearts; range of values. Virchows Arch 424(4):429-435. https://doi.org/10.1007/bf00190566

102. Soonpaa MH, Kim KK, Pajak L, Franklin M, Field LJ (1996) Cardiomyocyte DNA synthesis and binucleation during murine development. Am J Physiol 271(5 Pt 2):H2183-2189. https:// doi.org/10.1152/ajpheart.1996.271.5.H2183

103. Simões FC, Cahill TJ, Kenyon A, Gavriouchkina D, Vieira JM, Sun X, Pezzolla D, Ravaud C, Masmanian E, Weinberger M, Mayes S, Lemieux ME, Barnette DN, Gunadasa-Rohling M, Williams RM, Greaves DR, Trinh LA, Fraser SE, Dallas SL, Choudhury RP, Sauka-Spengler T, Riley PR (2020) Macrophages directly contribute collagen to scar formation during zebrafish heart regeneration and mouse heart repair. Nat Commun 11(1):600. https://doi.org/10.1038/s41467-019-14263-2

104. Ferraro B, Leoni G, Hinkel R, Ormanns S, Paulin N, OrtegaGomez A, Viola JR, de Jong R, Bongiovanni D, Bozoglu T, Maas SL, D'Amico M, Kessler T, Zeller T, Hristov M, Reutelingsperger C, Sager HB, Döring Y, Nahrendorf M, Kupatt C, Soehnlein O (2019) Pro-angiogenic macrophage phenotype to promote myocardial repair. J Am Coll Cardiol 73(23):2990_ 3002. https://doi.org/10.1016/j.jacc.2019.03.503

105. Liu B, Zhang HG, Zhu Y, Jiang YH, Luo GP, Tang FQ, Jian Z, Xiao YB (2017) Cardiac resident macrophages are involved in hypoxia-induced postnatal cardiomyocyte proliferation. Mol Med Rep 15(6):3541-3548. https://doi.org/10.3892/mmr.2017. 6432

106. Huang WC, Yang CC, Chen IH, Liu YM, Chang SJ, Chuang YJ (2013) Treatment of glucocorticoids inhibited early immune responses and impaired cardiac repair in adult zebrafish. PLoS One 8(6):e66613. https://doi.org/10.1371/journal.pone.0066613

107. Fadok VA, Bratton DL, Konowal A, Freed PW, Westcott JY, Henson PM (1998) Macrophages that have ingested apoptotic cells in vitro inhibit proinflammatory cytokine production through autocrine/paracrine mechanisms involving TGF-beta, PGE2, and PAF. J Clin Investig 101(4):890-898. https://doi.org/ 10.1172/JCI1112

108. Voll RE, Herrmann M, Roth EA, Stach C, Kalden JR, Girkontaite I (1997) Immunosuppressive effects of apoptotic cells. Nature 390(6658):350-351. https://doi.org/10.1038/37022 
109. Thompson RW, Pesce JT, Ramalingam T, Wilson MS, White S, Cheever AW, Ricklefs SM, Porcella SF, Li L, Ellies LG, Wynn TA (2008) Cationic amino acid transporter-2 regulates immunity by modulating arginase activity. PLoS Pathog 4(3):e1000023e1000023. https://doi.org/10.1371/journal.ppat.1000023

110. Han C, Nie Y, Lian H, Liu R, He F, Huang H, Hu S (2015) Acute inflammation stimulates a regenerative response in the neonatal mouse heart. Cell Res 25(10):1137-1151. https://doi.org/10. 1038/cr.2015.110

111. Lörchner H, Pöling J, Gajawada P, Hou Y, Polyakova V, Kostin S, Adrian-Segarra JM, Boettger T, Wietelmann A, Warnecke H, Richter M, Kubin T, Braun T (2015) Myocardial healing requires Reg3 $\beta$-dependent accumulation of macrophages in the ischemic heart. Nat Med 21(4):353-362. https://doi.org/10.1038/nm.3816

112. Wan E, Yeap XY, Dehn S, Terry R, Novak M, Zhang S, Iwata S, Han X, Homma S, Drosatos K, Lomasney J, Engman DM, Miller SD, Vaughan DE, Morrow JP, Kishore R, Thorp EB (2013) Enhanced efferocytosis of apoptotic cardiomyocytes through myeloid-epithelial-reproductive tyrosine kinase links acute inflammation resolution to cardiac repair after infarction. Circ Res 113(8):1004-1012. https://doi.org/10.1161/circresaha.113.301198

113. Furutani-Seiki M, Wittbrodt J (2004) Medaka and zebrafish, an evolutionary twin study. Mech Dev 121(7-8):629-637. https:// doi.org/10.1016/j.mod.2004.05.010

114. Gan P, Patterson M, Sucov HM (2020) Cardiomyocyte polyploidy and implications for heart regeneration. Annu Rev Physiol 82:45-61. https://doi.org/10.1146/annurev-physi ol-021119-034618

115. Hirose K, Payumo AY, Cutie S, Hoang A, Zhang H, Guyot R, Lunn D, Bigley RB, Yu H, Wang J, Smith M, Gillett E, Muroy SE, Schmid T, Wilson E, Field KA, Reeder DM, Maden M, Yartsev MM, Wolfgang MJ, Grützner F, Scanlan TS, Szweda LI, Buffenstein R, Hu G, Flamant F, Olgin JE, Huang GN (2019) Evidence for hormonal control of heart regenerative capacity during endothermy acquisition. Science 364(6436):184-188. https://doi.org/10.1126/science.aar2038

116. Li F, Wang X, Capasso JM, Gerdes AM (1996) Rapid transition of cardiac myocytes from hyperplasia to hypertrophy during postnatal development. J Mol Cell Cardiol 28(8):1737-1746. https://doi.org/10.1006/jmcc.1996.0163

117. Wills AA, Holdway JE, Major RJ, Poss KD (2008) Regulated addition of new myocardial and epicardial cells fosters homeostatic cardiac growth and maintenance in adult zebrafish. Development 135(1):183-192. https://doi.org/10.1242/dev.010363

118. Velayutham N, Alfieri CM, Agnew EJ, Riggs KW, Baker RS, Ponny SR, Zafar F, Yutzey KE (2020) Cardiomyocyte cell cycling, maturation, and growth by multinucleation in postnatal swine. J Mol Cell Cardiol 146:95-108. https://doi.org/10.1016/j. yjmcc.2020.07.004

119. Otto SP (2007) The evolutionary consequences of polyploidy. Cell 131(3):452-462. https://doi.org/10.1016/j.cell.2007.10.022

120. Zhang S, Zhou K, Luo X, Li L, Tu HC, Sehgal A, Nguyen LH, Zhang Y, Gopal P, Tarlow BD, Siegwart DJ, Zhu H (2018) The polyploid state plays a tumor-suppressive role in the liver. Dev Cell 44(4):447-459.e445. https://doi.org/10.1016/j.devcel.2018.01.010

121. Frawley LE, Orr-Weaver TL (2015) Polyploidy. Curr Biol 25(9):R353-358. https://doi.org/10.1016/j.cub.2015.03.037

122. Orr-Weaver TL (2015) When bigger is better: the role of polyploidy in organogenesis. Trends Genet 31(6):307-315. https:// doi.org/10.1016/j.tig.2015.03.011

123. Bennett AF, Ruben JA (1979) Endothermy and activity in vertebrates. Science 206(4419):649-654. https://doi.org/10.1126/ science. 493968

124. Lopaschuk GD, Collins-Nakai RL, Itoi T (1992) Developmental changes in energy substrate use by the heart. Cardiovasc Res 26(12):1172-1180. https://doi.org/10.1093/cvr/26.12.1172
125. Menendez-Montes I, Escobar B, Palacios B, Gómez MJ, Izquierdo-Garcia JL, Flores L, Jiménez-Borreguero LJ, Aragones J, Ruiz-Cabello J, Torres M, Martin-Puig S (2016) Myocardial VHL-HIF signaling controls an embryonic metabolic switch essential for cardiac maturation. Dev Cell 39(6):724-739. https:// doi.org/10.1016/j.devcel.2016.11.012

126. Puente BN, Kimura W, Muralidhar SA, Moon J, Amatruda JF, Phelps KL, Grinsfelder D, Rothermel BA, Chen R, Garcia JA, Santos CX, Thet S, Mori E, Kinter MT, Rindler PM, Zacchigna S, Mukherjee S, Chen DJ, Mahmoud AI, Giacca M, Rabinovitch PS, Aroumougame A, Shah AM, Szweda LI, Sadek HA (2014) The oxygen-rich postnatal environment induces cardiomyocyte cell-cycle arrest through DNA damage response. Cell 157(3):565-579. https://doi.org/10.1016/j.cell.2014.03.032

127. Cardoso AC, Lam NT, Savla JJ, Nakada Y, Pereira AHM, Elnwasany A, Menendez-Montes I, Ensley EL, Petric UB, Sharma G, Sherry AD, Malloy CR, Khemtong C, Kinter MT, Tan WLW, Anene-Nzelu CG, Foo RS, Nguyen NUN, Li S, Ahmed MS, Elhelaly WM, Abdisalaam S, Asaithamby A, Xing C, Kanchwala M, Vale G, Eckert KM, Mitsche MA, McDonald JG, Hill JA, Huang L, Shaul PW, Szweda LI, Sadek HA (2020) Mitochondrial substrate utilization regulates cardiomyocyte cell cycle progression. Nat Metab 2(2):167-178

128. Fuller SJ, Sivarajah K, Sugden PH (2008) ErbB receptors, their ligands, and the consequences of their activation and inhibition in the myocardium. J Mol Cell Cardiol 44(5):831-854. https:// doi.org/10.1016/j.yjmcc.2008.02.278

129. Gassmann M, Casagranda F, Orioli D, Simon H, Lai C, Klein R, Lemke G (1995) Aberrant neural and cardiac development in mice lacking the ErbB4 neuregulin receptor. Nature 378(6555):390-394. https://doi.org/10.1038/378390a0

130. Lee KF, Simon H, Chen H, Bates B, Hung MC, Hauser C (1995) Requirement for neuregulin receptor erbB2 in neural and cardiac development. Nature 378(6555):394-398. https://doi.org/ $10.1038 / 378394 \mathrm{a} 0$

131. D'Uva G, Aharonov A, Lauriola M, Kain D, Yahalom-Ronen Y, Carvalho S, Weisinger K, Bassat E, Rajchman D, Yifa O, Lysenko M, Konfino T, Hegesh J, Brenner O, Neeman M, Yarden Y, Leor J, Sarig R, Harvey RP, Tzahor E (2015) ERBB2 triggers mammalian heart regeneration by promoting cardiomyocyte dedifferentiation and proliferation. Nat Cell Biol 17(5):627-638. https://doi.org/10.1038/ncb3149

132. Meyer D, Birchmeier C (1995) Multiple essential functions of neuregulin in development. Nature 378(6555):386-390. https:// doi.org/10.1038/378386a0

133. Liu J, Bressan M, Hassel D, Huisken J, Staudt D, Kikuchi K, Poss KD, Mikawa T, Stainier DY (2010) A dual role for ErbB2 signaling in cardiac trabeculation. Development 137(22):3867-3875. https://doi.org/10.1242/dev.053736

134. Uribe V, Ramadass R, Dogra D, Rasouli SJ, Gunawan F, Nakajima H, Chiba A, Reischauer S, Mochizuki N, Stainier DYR (2018) In vivo analysis of cardiomyocyte proliferation during trabeculation. Development. https://doi.org/10.1242/dev.164194

135. Gemberling M, Karra R, Dickson AL, Poss KD (2015) Nrg1 is an injury-induced cardiomyocyte mitogen for the endogenous heart regeneration program in zebrafish. Elife. https://doi.org/10.7554/eLife.05871

136. Fukuda R, Aharonov A, Ong YT, Stone OA, El-Brolosy M, Maischein HM, Potente M, Tzahor E, Stainier DY (2019) Metabolic modulation regulates cardiac wall morphogenesis in zebrafish. Elife. https://doi.org/10.7554/eLife.50161

137. Salazar-Roa M, Malumbres M (2017) Fueling the cell division cycle. Trends Cell Biol 27(1):69-81. https://doi.org/10.1016/j. tcb.2016.08.009

138. Vander Heiden MG, Cantley LC, Thompson CB (2009) Understanding the Warburg effect: the metabolic requirements of cell 
proliferation. Science 324(5930):1029-1033. https://doi.org/10. 1126/science. 1160809

139. Yang W, Xia Y, Ji H, Zheng Y, Liang J, Huang W, Gao X, Aldape K, Lu Z (2011) Nuclear PKM2 regulates $\beta$-catenin transactivation upon EGFR activation. Nature 480(7375):118-122. https:// doi.org/10.1038/nature10598

140. Dasgupta S, Rajapakshe K, Zhu B, Nikolai BC, Yi P, Putluri N, Choi JM, Jung SY, Coarfa C, Westbrook TF, Zhang XH, Foulds CE, Tsai SY, Tsai MJ, O'Malley BW (2018) Metabolic enzyme PFKFB4 activates transcriptional coactivator SRC-3 to drive breast cancer. Nature 556(7700):249-254. https://doi.org/10. 1038/s41586-018-0018-1

141. Jeffery WR (2009) Regressive evolution in Astyanax cavefish. Annu Rev Genet 43:25-47. https://doi.org/10.1146/annur ev-genet-102108-134216

142. Aspiras AC, Rohner N, Martineau B, Borowsky RL, Tabin CJ (2015) Melanocortin 4 receptor mutations contribute to the adaptation of cavefish to nutrient-poor conditions. Proc Natl Acad Sci USA 112(31):9668-9673. https://doi.org/10.1073/pnas.1510802112

143. Riddle MR, Aspiras AC, Gaudenz K, Peuß R, Sung JY, Martineau B, Peavey M, Box AC, Tabin JA, McGaugh S, Borowsky R, Tabin CJ, Rohner N (2018) Insulin resistance in cavefish as an adaptation to a nutrient-limited environment. Nature 555(7698):647-651. https://doi.org/10.1038/nature26136

144. Hayes JP, Garland T Jr (1995) The evolution of endothermy: testing the aerobic capacity model. Evolution 49(5):836-847. https://doi.org/10.1111/j.1558-5646.1995.tb02320.x

145. Nespolo RF, Solano-Iguaran JJ, Bozinovic F (2017) Phylogenetic analysis supports the aerobic-capacity model for the evolution of endothermy. Am Nat 189(1):13-27. https://doi.org/10.1086/689598

146. Moorman AF, Christoffels VM (2003) Cardiac chamber formation: development, genes, and evolution. Physiol Rev 83(4):1223-1267. https://doi.org/10.1152/physrev.00006.2003

147. Sinclair J, Hoying D, Bresciani E, Nogare DD, Needle C, Wu W, Bishop K, Elkahloun A, Chitnis A, Liu P, Burgess S (2020) A metabolic shift to glycolysis promotes zebrafish tail regeneration through TGF- $\beta$ dependent dedifferentiation of notochord cells to form the blastema. bioRxiv. https://doi.org/10.1101/2020.03.03.975318

148. Benton MJ (1995) Diversification and extinction in the history of life. Science 268(5207):52-58. https://doi.org/10.1126/scien ce. 7701342

149. Falkowski PG, Katz ME, Milligan AJ, Fennel K, Cramer BS, Aubry MP, Berner RA, Novacek MJ, Zapol WM (2005) The rise of oxygen over the past 205 million years and the evolution of large placental mammals. Science 309(5744):2202-2204. https:// doi.org/10.1126/science. 1116047

150. Hsia CCW, Schmitz A, Lambertz M, Perry SF, Maina JN (2013) Evolution of air breathing: oxygen homeostasis and the transitions from water to land and sky. Compr Physiol 3(2):849-915. https://doi.org/10.1002/cphy.c120003

151. Payne JL, Boyer AG, Brown JH, Finnegan S, Kowalewski M, Krause RA Jr, Lyons SK, McClain CR, McShea DW, NovackGottshall PM, Smith FA, Stempien JA, Wang SC (2009) Twophase increase in the maximum size of life over 3.5 billion years reflects biological innovation and environmental opportunity. Proc Natl Acad Sci USA 106(1):24-27. https://doi.org/10.1073/ pnas.0806314106

152. Heallen T, Morikawa Y, Leach J, Tao G, Willerson JT, Johnson RL, Martin JF (2013) Hippo signaling impedes adult heart regeneration. Development 140(23):4683-4690. https://doi.org/ 10.1242/dev.102798

153. Leach JP, Heallen T, Zhang M, Rahmani M, Morikawa Y, Hill MC, Segura A, Willerson JT, Martin JF (2017) Hippo pathway deficiency reverses systolic heart failure after infarction. Nature 550(7675):260-264. https://doi.org/10.1038/nature24045

154. Aharonov A, Shakked A, Umansky KB, Savidor A, Genzelinakh A, Kain D, Lendengolts D, Revach OY, Morikawa Y, Dong J, Levin Y, Geiger B, Martin JF, Tzahor E (2020) ERBB2 drives YAP activation and EMT-like processes during cardiac regeneration. Nat Cell Biol 22(11):1346-1356. https://doi.org/10.1038/ s41556-020-00588-4

155. Bersell K, Arab S, Haring B, Kühn B (2009) Neuregulin1/ErbB4 signaling induces cardiomyocyte proliferation and repair of heart injury. Cell 138(2):257-270. https://doi.org/10.1016/j.cell.2009. 04.060

156. Magadum A, Singh N, Kurian AA, Munir I, Mehmood T, Brown K, Sharkar MTK, Chepurko E, Sassi Y, Oh JG, Lee P, Santos CXC, Gaziel-Sovran A, Zhang G, Cai CL, Kho C, Mayr M, Shah AM, Hajjar RJ, Zangi L (2020) Pkm2 regulates cardiomyocyte cell cycle and promotes cardiac regeneration. Circulation 141(15):1249-1265. https://doi.org/10.1161/circulationaha.119. 043067

Publisher's Note Springer Nature remains neutral with regard to jurisdictional claims in published maps and institutional affiliations. 